\title{
Tomasz Kucharski
}

Uniwersytet Mikołaja Kopernika, Toruń

t_kucharski@umk.pl

ORCID: https://orcid.org/0000-0002-5363-7529

\section{Aleksandra Wasielewicz}

Uniwersytet Mikołaja Kopernika, Torun

aleksandra.wasielewicz@gmail.com

ORCID: https://orcid.org/0000-0002-4614-3416

\section{Proceduralne aspekty odpowiedzialności dyscyplinarnej sędziów w II Rzeczypospolitej. Przebieg procesu w świetle akt osobowych i dyscyplinarnych sądów $z$ terenów dawnego zaboru pruskiego}

http://dx.doi.org/10.12775/SIT.2020.024

\section{Wprowadzenie}

Postępowanie dyscyplinarne przeciwko sędziom stanowi, również dzisiaj, kluczowy problem organizacji i funkcjonowania wymiaru sprawiedliwości. Jego uregulowanie powinno uwzględniać konieczność ochrony niezawisłości sędziowskiej, jednocześnie umożliwiając piętnowanie nagannych zachowań sędziów. Wpływa bowiem bezpośrednio na autorytet i odbiór społeczny profesji sędziowskiej oraz całego wymiaru sprawiedliwości. Problematyka ta w odniesieniu do 
czasów II Rzeczpospolitej nie budziła dotąd szczególnego zainteresowania naukowego. Dostępna literatura to najczęściej dogmatyczne refleksje przedwojennych prawników ${ }^{1}$. W pracach powojennych podejmowano ten temat raczej pobieżnie, bez analizy praktyki stosowania przepisów ${ }^{2}$. Warto przy tym pamiętać, że w świetle reguł archiwalnych akta spraw dyscyplinarnych oraz akta osobowe sędziów, kwalifikowano do kategorii $\mathrm{B}$, więc należało je brakować po upływie 50 lat $^{3}$. W konsekwencji większość materiału archiwalnego nie zachowała się. Jednakże kwerenda dotycząca terenów dawnego zaboru pruskiego: w Bydgoszczy, Inowrocławiu, Gdańsku, Poznaniu i Toruniu, dała pewne rezultaty, pozwalające ocenić praktykę

${ }^{1}$ Prace te są cenne, ale „skażone” ówczesną perspektywą i pozbawione szerokiego odniesienia do praktyki: A. Czerwiński, Ustrój sądów powszechnych, Lwów 1928; A. Beynarowicz, E. Ojak, O odpowiedzialności dyscyplinarnej sędziów, „Czasopismo Sędziowskie” 1931, nr 5-6; S. Gołąb, Organizacja sądów powszechnych opracowana systematycznie z uwzględnieniem rozwoju historycznego, sądownictwa szczególnego oraz ustroju adwokatury, prokuratorii generalnej i notariatu, Kraków 1938 oraz S. Gołąb, I. Rosenblüth, Ustrój sądów powszechnych, Warszawa 1929; E. Waśkowski, System procesu cywilnego, Wilno 1932; T. Kędzierski, Kilka uwag o sądach dyscyplinarnych dla sędziów i prokuratorów, „Głos Sądownictwa” 1934, nr 11.

${ }^{2}$ M. Materniak-Pawłowska, Ustrój sq̨downictwa powszechnego w II Rzeczpospolitej, Poznań 2003; eadem, Zawód sędziego w Polsce w latach 1918-1939, „Czasopismo Prawno-Historyczne” 2011, z. 1; M. Mohyluk, Prawo o ustroju sądów powszechnych w pracach Komisji Kodyfikacyjnej II Rzeczpospolitej, Białystok 2004; G. Ławnikowicz, Idea niezawisłości $w$ porzadku prawnym i myśli prawniczej II Rzeczpospolitej, Torun 2009; L. Krzyżanowski, Sędziowie $w$ II Rzeczpospolitej. Okręgi apelacyjne: krakowski i katowicki, Katowice 2011. Wyjątkiem jest szkic J. Moniuka, Udział prokuratora w postępowaniach dyscyplinarnych przeciw sędziom i prokuratorom apelacji toruńskiej - okres międzywojenny, „Studia Iuridica Toruniensia” 2014, nr 14.

${ }^{3}$ Por. K. Paterski, Zabezpieczanie dokumentacji osobowo płacowej zakładów pracy $w$ II poł. XX w. oraz u progu XXI w., „Problemy Archiwistyki” 2009, nr 1/1, s. 50. Okres przechowywania akt spraw dyscyplinarnych sędziów wynosił 50 lat - § 8 Rozporządzenia Ministra Sprawiedliwości z dnia 2 czerwca 1937 r. o przechowywaniu i niszczeniu akt i ksiąg w sprawach sądowych i administracji sądowej (Dz.U. 1937 nr 42 poz. 335), choć rozważano ich przechowywanie wieczyste; Archiwum Państwowe w Toruniu (dalej: APT), Sąd Okręgowy w Grudziądzu 1920-1939 (nr zespołu 1387) (dalej: SOG (1387)), sygn. 83, k. 1-16. 
międzywojennych sędziowskich postępowań dyscyplinarnych ${ }^{4}$. Kilka jednostek archiwalnych $\mathrm{z}$ takich postępowań zachowało się $\mathrm{w}$ bydgoskiej części zespołu Sądu Apelacyjnego w Toruniu ${ }^{5}$. Jednak najważniejszym materiałem okazały się teczki osobowe sędziów, które zawierały dokumentację spraw dyscyplinarnych, sądów okręgowych w Bydgoszczy oraz Grudziądzu ${ }^{6}$. Łącznie dało to 18 jednostek archiwalnych zawierających dokumentację spraw dyscyplinarnych.

Prezentowany artykuł został poświęcony proceduralnym aspektom przebiegu procesu dyscyplinarnego przeciwko sędziom w okresie międzywojennym na terenach dawnego zaboru pruskiego. Stan formalnoprawny skonfrontowano $z$ praktyką tam, gdzie było to możliwe $\mathrm{w}$ świetle zachowanych akt. Pozwoliło to ustalić, na ile efektywne były przyjęte rozwiązania, czy były one w pełni wykorzystywane i w jakim zakresie pozwalały chronić sędziowską niezawisłość oraz interes wymiaru sprawiedliwości.

\section{Zasady ogólne postępowania}

Po odzyskaniu niepodległości na terenach dawnego zaboru pruskiego postępowania dyscyplinarne prowadzono na podstawie ustawy pruskiej z 1851, znowelizowanej w 1856 r. ${ }^{7}$ Po ujedno-

${ }^{4}$ Problemy kwerendy w aktach spraw sądowych zob. T. Kucharski, Akta spraw sądowych i orzecznictwo sądowe z okresu II RP jako źródło historyczne. Węzłowe problemy archiwalne i metodologiczne na przykładzie badań nad fideikomisami familijnymi, „Krakowskie Studia z Historii Państwa i Prawa” 2020, z. 1, s. 25-50.

${ }^{5}$ Archiwum Państwowe w Bydgoszczy (dalej: ABP), Sąd Apelacyjny w Toruniu (nr zespołu: 59) (dalej: SAT (59)), sygn. 47, 50, 52, 53, 55.

${ }^{6} \mathrm{~W}$ pierwszym zachowały się teczki 36 sędziów (uzyskano dostęp do 31 ) sprawy dyscyplinarne znajdują się w czterech (dla czterech sędziów); APB, Sąd Okręgowy w Bydgoszczy (nr zespołu: 65) (dalej: SOB (65)), sygn. 691, 759, 792, 818. W drugim zachowały się 34 teczki sędziowskie - sprawy dyscyplinarne zawiera 10 (względem ośmiu sędziów), APT, SOG (1387), sygn. 582-583, 605, 615, 628, 649, 657, 699-700, 735.

7 Ustawa tycząca się przewinień służbowych sędziów i mimowolnego przesadzenia takowych na inne miejsce albo w nieczynność z 7 maja 1851 r., 
liceniu ustroju wymiaru sprawiedliwości rozwiązania te zostały uchylone i zastąpione przepisami rozdziału VII „Prawa o ustroju sądów powszechnych" z 1928 r. $^{8}$ Oba te akty przejawiają wiele podobieństw, gdyż polski prawodawca silnie inspirował się rozwiązaniami pruskimi. Możliwe jest zatem rekonstruowanie wspólnych zasad ogólnych rządzących postępowaniem dyscyplinarnym dla całego okresu II RP.

Przedwojenna procedura dyscyplinarna wywodziła się z ówczesnej procedury karnej. Wykorzystano w niej zresztą uniwersalną regułę odpowiedniego stosowania przepisów procedury karnej w kwestiach nieuregulowanych ${ }^{9}$. Do procedury dyscyplinarnej odniesienie miała zatem większość zasad ogólnych postępowania karnego ${ }^{10}$. Najważniejszymi $z$ nich były: zasada prawdy materialnej (zgodności z rzeczywistym stanem rzeczy), zasada swobodnej oceny dowodów ${ }^{11}$, zasada wieloinstancyjności postępowania ${ }^{12}$, zasada

„Gesetz-Sammlung für die Königlichen Preussischen Staaten” [„Zbiór Praw dla Państw Królestwa Pruskiego"] 19.04.1856, nr 13/3358, s. 326-351 (dalej: p.u.d.); Ustawa tycząca się niektórych zmian ustawy względem przewinień służbowych sędziów z dnia 7 maja 1851 (zbiór praw s. 326) i zaprowadzenia rady honorowej dla obrońców praw przy głównym trybunale, $z$ dnia 26 marca 1856, „Gesetz-Sammlung für die Königlichen Preussischen Staaten” [,Zbiór Praw dla Państw Królestwa Pruskiego"] 19.04.1856, nr 17/4386, s. 331-333.

${ }^{8}$ Rozporządzenie Prezydenta Rzeczypospolitej z dnia 6 lutego 1928 r. Prawo o ustroju sądów powszechnych, Dz.U.1928, nr 12 poz. 93 (dalej: p.u.s.p.).

$9 \S 43$ p.u.d. oraz art. 181 p.u.s.p.

${ }^{10}$ O zasadach międzywojennej procedury karnej: E. Krzymuski, Wykład procesu karnego ze stanowiskiem nauki i prawa obowiązujacego $w$ b. dzielnicy austrjackiej oraz z uwzględnieniem ważniejszych różnic na innych ziemiach Polski, Kraków 1922, s. 9-20; Historia państwa i prawa Polski 1918-1939, część II, red. F. Ryszka, Warszawa 1968, s. 110-115 oraz w zakresie wpływów szkoły socjologicznej J. Koredczuk, Wpływ nurtu socjologicznego na kształt polskiego prawa karnego procesowego w okresie międzywojennym (Les classiques modernes), Wrocław 2007, passim.

11 Ustawa p.u.d. wyraźnie odrzucała „pozytywne reguły dowodu”, czyli pozytywną legalną teorię dowodową na rzecz swobodnej oceny dowodów. Sędzia rozstrzygał więc sprawę „według swego wolnego z całego ogółu czynności i dowodów czerpanego przekonania”.

12 Por. § 35 i n. p.u.d.; art. 165 i n. p.u.s.p. 
ochrony praw obwinionego ${ }^{13}$ (do obrony oraz domniemania jego niewinności) ${ }^{14}$. Niektóre $z$ zasad procedury karnej były akceptowane tylko w pewnym zakresie - zwłaszcza zasada ustności rozprawy i bezpośredniości przeprowadzania dowodów na rozprawie ${ }^{15}$. Ostatnią z zasad omawianej procedury dyscyplinarnej, nieznaną ówczesnemu procesowi karnemu, była zasada tajności ${ }^{16}$. Oznaczała ona przede wszystkim wyłączenie jawności zewnętrznej rozpraw i silne ograniczenie możliwości uzyskania dostępu do informacji o przebiegu procesu przez opinię publiczną. Informacje takie miały być przekazywane społeczeństwu wyłącznie w sytuacjach wyjątkowych i tylko $\mathrm{w}$ formie opublikowania wydanego już w sprawie prawomocnego wyroku (na mocy uchwały sądu dyscyplinarnego oraz odrębnej zgody ministra sprawiedliwości) ${ }^{17}$. Celem wprowadzenia tych zabiegów była potrzeba ochrony autorytetu wymiaru sprawiedliwości. Uznawano, że zaznajomienie opinii publicznej z błędami popełnianymi przez sędziów, czy nawet ich niegodziwościami, mogłoby zmniejszyć szacunek stron postępowania do konkretnych sędziów prowadzących ich sprawy oraz wpłynąć negatywnie na powagę sądów w ogóle. W międzywojennej literaturze prawniczej tajność postępowania uważano za rozwiązanie trafne. Wskazywano, że: „sprawy te dotyczą naruszeń wewnętrznego porządku służbowego lub zachowywania się sędziów w życiu prywatnym, przeto publiczne rozpoznanie ich niczego publiczności nie nauczy, wcale jej nie odstraszy, a tylko rozbudzi niezdrową ciekawość i uczyni sędziów przedmiotem plotek. W rezultacie publiczność postępowania podkopuje w społeczeństwie szacunek i zaufanie do sędziów [...]”18.

${ }^{13}$ W aktach używa się zamiennie zwrotu „oskarżony”, nawiązującego do procedury karnej. Dla ujednolicenia terminologii używamy określenia „obwiniony", użytego również w rozporządzeniu z $1928 \mathrm{r}$.

14 Por. § 30 zd. 2 i 4, 31, 32 p.u.d.; art 145, $146 \S 2,147 \S 1,152$ § 1, 162 $\S 2$ p.u.s.p.

${ }^{15}$ Por. $§ 31$ p.u.d. oraz art. 159 zd. 2 i 3.

${ }^{16} \mathrm{~W}$ ustawie pruskiej - w odniesieniu do rozprawy - § $30 \mathrm{zd}$. 1, w polskim rozporządzeniu do całego postępowania art. $146 \S 1$ p.u.s.p. („postępowanie dyscyplinarne jest tajne").

17 Por. art. $146 \S 3$ p.u.s.p.

18 E. Waśkowski, op.cit., s. 81. 
Trudno nie zgodzić się z poglądem, że jawność postępowania może przyczynić się do osłabiania szacunku i zaufania do sędziów. Dziwi jednak jednostronność takiego podejścia. Prowadziło ono bowiem do lekceważenia ewentualności wystąpienia nadużyć w prowadzeniu postępowań. Szczególnie, że takie rozwiązanie nie było transparentne względem opinii publicznej, co mogło rodzić plotki i sprawiać wrażenie bezkarności sędziów. Zbadane przez nas akta spraw dyscyplinarnych przekonują jednak, że zasada tajności postępowania nie stała na przeszkodzie skutecznemu reagowaniu na przewinienia sędziów ${ }^{19}$.

\section{Właściwość rzeczowa sądów}

Właściwość sądów w pruskiej ustawie określał § 18, zmieniony na potrzeby odrodzonego państwa polskiego, przez Rozporządzenie Ministra b. Dzielnicy Pruskiej z 21 czerwca 1920 r. zmieniające niektóre przepisy o postępowaniu dyscyplinarnem przeciw sędziom ${ }^{20}$. Po 1928 r. właściwość sądów w sprawach dyscyplinarnych sędziów określał art. 137 p.u.s.p.

Mimo pewnych różnic w organizacji ustroju sądów w dobie przed unifikacją i po niej zasady właściwości w sędziowskich sprawach dyscyplinarnych były niemal niezmienne przez cały okres II RP. Sprawy sędziów sądów niższych instancji (powiatowych, potem grodzkich i okręgowych) rozpatrywały właściwe sądy dyscyplinarne dla okręgów apelacyjnych, natomiast sprawy sędziów pełniących swój urząd w sądach wyższych (apelacyjnych i Najwyższym) kierowane były do Wyższego Sądu Dyscyplinarnego (złożonego z sędziów

19 Dziś zasada tajności postępowania byłaby niezgodna z Konstytucją i standardami dostępu do informacji publicznej. Pomijając kontrowersje wokół Izby Dyscyplinarnej SN, sędziowskie postępowania dyscyplinarne są „postępowaniami sądowymi” sensu stricto (prowadzonymi przed niezawisłymi sądami), muszą realizować zasady wynikające $z$ art. 45 Konstytucji i art. 6 Europejskiej konwencji praw człowieka. Zob. K. Kremens, Jawność prokuratorskich postępowań dyscyplinarnych, „Prokuratura i Prawo” 2015, nr 5, s. 132.

20 Dz.Urz.Min.b.Dz.Pr. 1920 r., nr 34, poz. 296. O przedunifikacyjnym ustroju sądów w dawnej dzielnicy pruskiej zob. M. Materniak-Pawłowska, Ustrój sądownictwa, s. 125. 
Sądu Najwyższego), od którego odwołania przyjmował Najwyższy Sąd Dyscyplinarny (również złożony z sędziów Sądu Najwyższego) ${ }^{21}$.

\section{Stadia postępowania dyscyplinarnego}

Przedwojenne postępowanie dyscyplinarne wywodziło się z postępowania karnego i podobnie jak ono dzieliło się na stadia. Pierwszym z nich była jednolita forma postępowania przygotowawczego - śledztwo. Nie było ono obligatoryjne, gdyż w przypadku spraw mniej skomplikowanych sąd, wszczynając postępowanie, mógł od razu zarządzić rozprawę główną.

W aktach dla nazwania tego stadium zamiennie używano terminów: „dochodzenie”22 (ew. „dochodzenie przygotowawcze” ${ }^{23}$ lub „dochodzenie dyscyplinarne”"24), „śledztwo wstępne”25 i „śledztwo dyscyplinarne" 26 . Brak jednolitej terminologii był najprawdopodobniej skutkiem używania niemieckich tekstów ustaw i odmiennego tłumaczenia przepisów, w zależności od składu orzekającego. Niejasności terminologiczne napotkać można także w sprawach prowadzonych na gruncie rozporządzenia z 1928 r. Choć nazywa ono omawiane stadium „śledztwem”, w aktach stosuje się często termin „dochodzenie” ${ }^{27}$. Stanowi to ciekawy przykład napięcia między tendencją do ujednolicenia i polonizowania prawa $\mathrm{w}$ okresie międzywojennym a edukacją i przyzwyczajeniami pracowników wymiaru sprawiedliwości.

${ }^{21}$ Właściwość sądu określało stanowisko zajmowane w chwili wszczęcia postępowania, nawet jeśli obwiniony w toku postępowania objął stanowisko w innym sądzie. Właściwość sędziów w stanie spoczynku określało stanowisko zajmowane w chwili przejścia w ten stan; art. $137 \S 2$ p.u.s.p.

${ }^{22}$ Np. APB, SAT (59), sygn. 53, k. 2 i 7.

${ }^{23}$ Np. APB, SAT (59), sygn. 52, k. 2.

${ }^{24}$ Np. APB, SAT (59), sygn. 47, k. 1.

${ }^{25}$ Np. APT, SOG (1387), sygn. 649, k. 76v.

${ }^{26}$ Np. APB, SAT (59), sygn. 50, k. 7.

${ }^{27}$ Zob. art. 148-152 p.u.s.p. Należy jednak dodać, że w p.u.s.p. nie trzymano się jednolitej terminologii, art. 159 § 1 stanowił o aktach i dowodach dostarczonych w „dochodzeniu i śledztwie”. 
Kolejnym stadium postępowania była rozprawa główna I instancji, prowadzona przed właściwym sądem dyscyplinarnym. W ustawie pruskiej nazywano ją „ustną rozprawą"28, a w rozporządzeniu z 1928 r. „rozprawą" ${ }^{29}$. W aktach przeważa określenie „rozprawa”, używano też nazw: „rozprawa główna” ${ }^{30}$ czy też „ustna rozprawa” ${ }^{31}$.

Zgodnie $z$ zasadą wieloinstancyjności postępowania możliwe było odwołanie do sądu wyższej instancji. Zatem kolejnym stadium postępowania dyscyplinarnego, o ile skorzystano ze środków zaskarżenia, było postępowanie odwoławcze (II instancji). W dalszej kolejności, po uprawomocnieniu się wyroku, postępowanie przechodziło w stadium wykonawcze, którego celem było wykonanie zapadłego orzeczenia ${ }^{32}$.

\section{Przebieg postępowania}

Postępowanie dyscyplinarne wszczynane było z zasady na wniosek uprawnionego organu ${ }^{33}$. Ustawa pruska znała co prawda dwa tryby

${ }^{28}$ Zob. § 17, 28, 30 p.u.d.

29 Zob. art. $157-160$ p.u.s.p.

30 Np. APB, SAT (59), sygn. 55, k. 3.

${ }^{31}$ Np. APB, SAT (59), sygn. 47, k. 1.

32 P.u.s.p. zawierało regulacje skutków wyroku dyscyplinarnego. Wykonanie wyroku, w zależności od orzeczonej kary, należało do ministra sprawiedliwości oraz prezesa sądu apelacyjnego lub I prezesa Sądu Najwyższego (art. 168 § 2 p.u.s.p.). Odpis prawomocnego wyroku skazującego na karę dyscyplinarną dołączano do akt osobowych skazanego, jednocześnie zamieszczając o nim wzmiankę w wykazie służbowym (art. 176 § 1 p.u.s.p.). Analogicznie postępowano także przed 1928 r.; APT, SOG (1387), sygn. 582, nlb., sygn. 605, nlb. oraz sygn. 735, nlb. Jeżeli w przeciągu pięciu kolejnych lat skazany nie popełnił kolejnego przewinienia dyscyplinarnego i nie został skazany innym wyrokiem, minister sprawiedliwości na wniosek zainteresowanego sędziego zarządzał sporządzenie nowego wykazu służbowego (art. 176 p.u.s.p.). W razie śmierci obwinionego przed wydaniem wyroku sąd umarzał postępowanie. Jeśli obwiniony sędzia w toku postępowania wystąpił ze służby sędziowskiej, postępowanie powinno toczyć się dalej. W przypadku, gdy obwiniony przechodził do innej służby państwowej, adwokatury, notariatu lub służby samorządowej, sąd przesyłał wyrok nowym przełożonym (art. 167 p.u.s.p.).

33 Przyczyną podjęcia czynności mogło być doniesienie osoby fizycznej, w ja- 
wszczęcia postępowania dyscyplinarnego - na wniosek prokuratora oraz z urzędu, ale po „słuchanym” wniosku prokuratora ${ }^{34}$. Na gruncie ustawy unifikacyjnej postępowanie wszczynane było już tylko na wniosek składany przez władzę nadzorczą (czyli przełożonego sędziego) ${ }^{35}$. Zmniejszono tu jednak znacząco pozycję prokuratora, co miało na celu poszerzenie gwarancji procesowych obwinionego niezawisłego sędziego. O dokonaniu pierwszej czynności na drodze do pociągnięcia go do odpowiedzialności dyscyplinarnej decydował odtąd wyłącznie inny przedstawiciel profesji sędziowskiej ${ }^{36}$. Zgodnie $\mathrm{z}$ przepisami polskimi, co nie miało odpowiednika $\mathrm{w}$ prawie pruskim, przed złożeniem sądowi dyscyplinarnemu wniosku władza nadzorcza miała obowiązek dokonać wstępnego wyjaśnienia okoliczności koniecznych do „ustalenia znamion przewinienia” ${ }^{37}$. Jednocześnie należało na tym etapie stworzyć obwinionemu sędziemu

kiejkolwiek formie, por. np. w sprawie sędziego J. Giertycha (w rzeczywistości P. Konizera) z 1934 r. - APB, SOB (65), k. 2-3v.

${ }^{34} \S 24$ p.u.d. Pewną nieścisłością jest twierdzenie, że wszczęcie postępowania według ustawy pruskiej następowało na wniosek prokuratora lub z urzędu (por. J. Moniuk, op.cit., s. 226). Drugi z tych trybów podejmowany był bowiem wyłącznie po wysłuchaniu wniosku prokuratora. Nie był to zatem klasyczny tryb wszczynania postępowania $z$ urzędu. Stosowania tego trybu nie odnotowaliśmy w praktyce; w przebadanych sprawach postępowania wszczynał sąd na wniosek prokuratora; np. APT, SOG (1387), sygn. 582, k. 103.

${ }^{35}$ Art. 70 p.u.s.p. Nadzór nad sądami i sędziami pełnili: kierownik sądu nad swoim sądem; naczelnik sądu grodzkiego także nad sędziami pokoju swego okręgu; prezes sądu okręgowego - nad sądami grodzkimi wraz z sędziami pokoju swego okręgu; prezes sądu apelacyjnego - nad sądami okręgowymi i grodzkimi wraz z sędziami pokoju swego okręgu.

${ }^{36}$ Wnioski kierowników sądów z okresu po 1928 r.: APB, SOB (65), sygn. 691, k. 74-74v; APT, SOG (1387), sygn. 605, k. 1-1v; APT, SOG (1387), sygn. 628, k. 128a-128av.

${ }^{37}$ Był to najczęściej szeroki zakres czynności wstępnych. Tak np. w związku z zarzutami wobec sędziego P. Konitzera, prezes sądu apelacyjnego wnosił do prezesa sądu okręgowego „o przeprowadzenie odpowiednich dochodzeń administracyjnych, a w szczególności przesłuchania świadków [...] poczem wystąpienie do sądu dyscyplinarnego z [...] wnioskiem przeciwko sędziemu”. Ten etap postępowania mógł trwać długo, niekiedy niemożność przesłuchania świadków wymagała uzyskania dodatkowego czasu na przeprowadzenie czynności wstępnych; APB, SOB (65), sygn. 686, k. 15, 24, 31, 38, 38v. 
sposobność do złożenia wyjaśnień ${ }^{38}$. Jeśli kierownik sądu zdecydował się złożyć wniosek o wszczęcie postępowania dyscyplinarnego, o losie tego wniosku decydował sąd dyscyplinarny - rozpatrywał go na niejawnym posiedzeniu, zwoływanym przez przewodniczącego ${ }^{39}$. Według przepisów polskich z 1928 r. sąd miał tu możliwość wysłuchania stanowiska kierownika sądu lub innego wyznaczonego sędziego. W razie uwzględnienia wniosku sąd wydawał uchwałę wszczynającą postępowanie dyscyplinarne, w której określał dokładne zarzuty, w przedmiocie których miało się ono toczyć ${ }^{40}$. Sąd mógł także wydać uchwałę odmawiającą wszczęcia postępowania, jeśli uznał zarzuty za niezasadne ${ }^{41}$. W takim przypadku prokuratorowi dyscyplinarnemu ${ }^{42}$ służyła skarga do sądu wyższej instancji ${ }^{43}$. Zadaniem postępowania dyscyplinarnego była głównie ochrona interesu wymiaru sprawiedliwości, w konsekwencji często elastycznie rezygnowano $z$ niego, stosując inne instrumenty radzenia sobie z nieodpowiednimi zachowaniami sędziów. Najczęściej na sędziego

38 Art. 147 § 1 p.u.s.p. Przepis ten był stosowany. Wezwania do ustosunkowania się oraz odpowiedzi na nie znajdują się w aktach w sprawach J. Giertycha i P. Konizera; APB, SOB (65), sygn. 686, k. 1, 4 i 11.

${ }^{39}$ Zarządzenia zwołujące: APT, sygn. 615, k. 16; APT, sygn. 735, k. 206. Protokoły: APT, sygn. 735, k. 207.

40 Zob. APT, SOG (1387), sygn. 605, k. 1; sygn. 735, k. 208-209v. W aktach używano zwrotu „wdrożenie postępowania”; por. APT, SOG (1387), sygn. 582, k. 113; APT, SOG (1387), sygn. 649, k. 76; sygn. 700, k. 21.

${ }^{41} \S 25$ p.u.d. i art. $147 \S 4$ p.u.s.p. Taka uchwała zapadła np. w sprawie sędziego I. Chwojki. W 1927 r. zarzucono mu niestosowne komentarze pod adresem świadków w trakcie rozprawy karnej w I instancji (miał stwierdzić, że robotnik nie może być wiarygodnym świadkiem). Decydujące znaczenie dla uchwały odmawiającej wszczęcia postępowania miały sprzeczne zeznania świadków zdarzenia. Jednocześnie sąd karny rozstrzygający apelację przyjął w wyroku, że omawiana sytuacja z udziałem sędziego rzeczywiście się wydarzyła. Sąd dyscyplinarny uznał jednak, że „nie jest krępowany tem wyrzeczeniem sądu karnego i rozpatrując sprawę wedle swobodnej oceny danego materiału dowodowego może przyjść do innego przekonania”. Sąd powołał zasadę swobodnej oceny (§ 33 p.u.d.), odrzucając powage rzeczy osądzonej; por. APB, SOB (65), sygn. 792, k. 75-78. Uchwała o oddaleniu wniosku także w sprawie J. Kłosińskiego: APT, SOG (1387), sygn. 628, k. 162-163.

${ }^{42}$ Definicja w art. $143 \S 2$ p.u.s.p.

${ }^{43} \S 26$ p.u.d. i art. $147 \S 4$ p.u.s.p. 
nienadającego się do zawodu wywierano nieformalną presję, by zrezygnował z funkcji - „wypychano” go po prostu do innego zawodu prawniczego $^{44}$, co nierzadko budziło opór palestry ${ }^{45}$. Stosowano też możliwość szybkiego usuwania sędziego na podstawie art. 110c p.u.s.p. ${ }^{46}$ Zdarzały się także przypadki zwracania uwagi sędziom

${ }^{44}$ Tak w sprawie sędziów Kuczyńskiego i Heringa. Ciążyły na nich zarzuty dotyczące niesumienności i nieterminowości załatwiania spraw, opuszczania sądu przed końcem godzin pracy i niepowracania $z$ urlopu. Prezes sądu deklarował: „na razie wstrzymałem się z wytoczeniem tym sędziom postępowania dyscyplinarnego”. O jednym z nich pisał: „zobowiązał się służyć pięć lat w sądownictwie, świadomie w ten sposób postępuje, aby po upływie dwóch lat móc przejść do adwokatury [...] w interesie służbowym nie należałoby w tym przeszkadzać”. Oceniając drugiego, pisał: „siedzi dłużej w biurze, lecz jest bardzo słabym sędzią o mniej jak przeciętnych zdolnościach” i „nie ma zamiaru wystąpić $z$ sądownictwa, bo w adwokaturze nie dałby sobie rady, lecz jego ustąpienie [...] byłoby [...] pożądanem”; APB, SOB (65), sygn. 791, nlb.

${ }^{45} \mathrm{~W}$ uchwale Izby Adwokackiej w Toruniu domagano się prawidłowego zakończenia postępowania dyscyplinarnego przeciwko S. Filipowskiemu, sprzeciwiając się jego „polubownemu” przejściu do palestry: „adwokat powinien mieć te same kwalifikacje moralne co sędzia. Nie uchodzi, żeby adwokaci sędziego, którego się jego własna władza przełożona pozbywa po wytoczeniu aktu oskarżenia w postępowaniu dyscyplinarnemu, do swego grona przyjmowali [...], ujmę by przyniósł stanowi adwokackiemu. Jeżeli nie miał poszanowania dla zaszczytnego stanu sędziowskiego [...], to można sobie wystawić, jak sobie będzie postępował [...], dopuszczony do wolnego stanu adwokackiego"; APT, SOG (1387), sygn. 582, k. 111.

${ }^{46}$ Było to przymusowe przeniesienie w stan spoczynku z uwagi na ,interes wymiaru sprawiedliwości” uchwałą zgromadzenia ogólnego sądu. Mechanizm ten można było łączyć $z$ wywieraniem presji - żądano od sędziego dobrowolnej rezygnacji, grożąc $w$ przeciwnym razie surowym środkiem $z$ art. 110c. Na przykład do sędziego P. Kanitzera, którym popełnił bardzo poważne uchybienia, prezes sądu pisał: „zachowanie się Pana Sędziego zwłaszcza poza służbą uwłacza wszelkiej godności sędziego i obniża powagę i autorytet sądownictwa polskiego. Nadto stwierdzonem zostało, że praca Pana Sędziego jest bardzo mało wydajną [...], co wywołuje nieustanne zażalenia i ujemne ustosunkowanie się stron do sądownictwa polskiego [...], uznaję, że w interesie dobra wymiaru sprawiedliwości zachodzi konieczna potrzeba usunięcia Pana z zajmowanego stanowiska Sędziego [...]. W tym celu zamierzam wystąpić z umotywowanym wnioskiem [...] o przeniesienie Pana z urzędu w stan spoczynku w myśl art. 110 lit. c prawa o ustroju sadów powszechnych [...] pozostawiam Panu Sędziemu 14to dniowy termin do wniesienia podania o przeniesienie Go w stan spoczynku 
w trybie nadzoru nad ich pracą zamiast wszczynania postępowań dyscyplinarnych lub równolegle $z$ ich prowadzeniem ${ }^{47}$.

Jeśli było to konieczne, nakazywano przeprowadzenie śledztwa uchwałą wszczynającą postępowanie, wyznaczając sędziego do jego przeprowadzenia ${ }^{48}$. W sprawach prostszych rezygnowano $z$ tego stadium i od razu zarządzano rozprawę ${ }^{49}$. Sędzia prowadzący śledztwo badał okoliczności sprawy i zbierał dowody, nie będąc przy tym skrępowanym treścią uchwały o wszczęciu postępowania ${ }^{50}$. Niestety niewiele wiemy o praktycznej stronie pracy sędziego prowadzącego śledztwo i w ogóle o przebiegu tego stadium - zachowane dokumenty są raczej skąpe, rzadko zawierają świadectwa podejmowanych czynności. Również uchwały o wszczęciu postępowania nakazujące prowadzenie śledztwa nie podają ważnych informacji ${ }^{51}$.

[...] na własne żądanie”; APB, SOB (65), sygn. 686, k. 216-216v. Por wniosek dotyczący J. Kosińskiego: APT, SOG (1387), sygn. 628, k. 120-120v, 152-152v oraz W. Majewskiego: APT, SOG (1387), sygn. 657, k. 128v-139. Art. 110c był alternatywą dla postępowań dyscyplinarnych w sprawach, gdzie szkodliwość sędziego była ewidentna, a podjęcie szybkich działań pożądane.

${ }^{47}$ Art. 72 § 1 p.u.s.p.; por. np. w piśmie z 1929 r. sędzia M. Frankowski został upomniany za niewybredne komentarze względem wydanego przez prezesa sądu zarządzenia. Prezes poprzestał na pisemnej reprymendzie, rezygnując ze ścieżki postępowania dyscyplinarnego. Rok później ten sam sędzia został ponownie skrytykowany przez prezesa sądu, tym razem za poważniejsze przewinienia (nieprzestrzeganie drogi służbowej), zwalnianie się z obowiązków bez zgody kierownika, notoryczne spóźnianie się na rozprawy i błędne konstruowanie sentencji wyroków; APB, SOB (65), sygn. 691, k. 76. Tym razem obok pisemnej reprymendy prezes wystąpił $z$ wnioskiem o wszczęcie postępowania dyscyplinarnego. Sędzia pod presją sam zrezygnował ze stanowiska; ibidem, k. 69.

${ }^{48} \S 23$ p.u.d. oraz art. $147 \S 2$ i art. 148 p.u.s.p.

49 Tak w uchwale sądu dyscyplinarnego w sprawie S. Filipowskiego; APT, SOG (1387), sygn. 583, k. 113.

$50 § 27$ p.u.d. oraz art. 149 p.u.s.p. i 150 p.u.s.p.

${ }^{51} \mathrm{Na}$ przykład w sprawie W. Lundblada nakazano „wdrożyć [...] śledztwo wstępne”. Brakuje tu nazwiska wyznaczonego sędziego i zakresu czynności, które miałby on podjąć; APT, SOG, sygn. 649, k. 76-76v. Nie zachowała się dokumentacja śledztwa ani ostateczny wniosek prokuratora, stanowiący jego podsumowanie. Nawet zachowane wnioski prokuratorów kończące śledztwo nie dają jego szerszego obrazu. Zawierają tylko niekiedy odwołania do numerów 
Po zakończeniu śledztwa przez wyznaczonego sędziego ${ }^{52}$ prokurator sporządzał swoisty „akt oskarżenia” (w rozporządzeniu z 1928 r. zwany „wnioskiem prokuratora” ${ }^{53}$. Zarówno według ustaw pruskich, jak i p.u.s.p. zarządzano wówczas rozprawę główną ${ }^{54}$. Według polskich przepisów na tym etapie sąd miał także możliwość, by zarządzić uzupełnienie śledztwa lub umorzyć postępowanie ${ }^{55}$. Jeśli wymierzał tylko karę upomnienia, mógł również wydać wyrok skazujący bez przeprowadzenia rozprawy ${ }^{56}$.

Przepisy przewidywały środek zapobiegawczy w postaci zawieszenia w czynnościach służbowych. Sąd dyscyplinarny mógł z niego skorzystać w przypadkach, w których przemawiała za tym waga przewinień popełnionych przez sędziego ${ }^{57}$. Według przepisów pruskich zawieszony sędzia otrzymywał połowę uposażenia ${ }^{58}$, natomiast jeżeli został uniewinniony, zwracano mu zatrzymaną część uposażenia ${ }^{59}$. Przepisy polskie przewidywały, że jeżeli sędziego „zaaresztowano" z powodu schwytania go na gorącym uczynku albo jeżeli ze względu na rodzaj czynu sędziego powaga sądu lub istotne interesy służby wymagały błyskawicznego odsunięcia go od wykonywania obowiązków, władza nadzorcza mogła zarządzić natychmiastową przerwę $\mathrm{w}$ ich wykonywaniu, aż do postanowienia sądu. O zarządzeniu należało zawiadomić sąd, który powinien niezwłocznie wydać

kart niezachowanych akt śledztwa; APT, SOG (1387), sygn. 582, k. 103-105v. Odniesienia te na pewno obejmowały protokoły z zeznaniami świadków; ibidem, k. 105v.

${ }^{52}$ Według § 27 p.u.d. prokuratura mogła stwierdzić konieczność kontynuowania śledztwa.

${ }^{53}$ Art. 152 p.u.s.p. W aktach też „akt oskarżenia”; np. APT, SOG (1387), sygn. 649, k. 85v; sygn. 582, k. 103.

${ }^{54} \S 29$ p.u.d.

55 Art. 153 p.u.s.p. Na uchwałę umarzającą postępowanie prokuratorowi służyła skarga.

${ }^{56}$ Odpis wyroku z uzasadnieniem doręczano wówczas prokuratorowi i obwinionemu, którzy mogli zażądać w ciągu siedmiu dni przeprowadzenia rozprawy (art. 155 p.u.s.p.); por. APT, SOG (1387), sygn. 605, k. 18-20, 28.

${ }^{57} \S 46$ p.u.d. oraz art. 182 p.u.s.p.

58 § 48 p.u.d.

${ }^{59} \S 49$ p.u.d. 
uchwałę o zawieszeniu sędziego ${ }^{60}$. Podczas zawieszenia uposażenie sędziowskie mogło zostać ograniczone nawet do połowy jego wysokości ${ }^{61}$. W sprawach zbadanych na potrzeby artykułu natrafiono na dwa przypadki zawieszenia w czynnościach służbowych. W pierwszym sąd uzasadniał użycie tego środka "powagą wytoczonych zarzutów”62, a w drugim „wielkością zarzucanego przewinienia”, „powagą sądu” i „interesami służby”63.

Rozprawa mogła być zwołana bezpośrednio w uchwale sądu dyscyplinarnego o wszczęciu postępowania, gdy rezygnowano $\mathrm{z}$ przeprowadzenia śledztwa. Jeśli stadium postępowania przygotowawczego było zachowane, po jego zakończeniu i złożeniu wniosku prokuratora wyznaczano ją zarządzeniem przewodniczącego sądu ${ }^{64}$. Podczas rozprawy wymagano obecności obwinionego, gdyż był on przesłuchiwany ${ }^{65}$. Według przepisów pruskich obwiniony mógł korzystać $z$ pomocy adwokata lub pełnomocnika ${ }^{66}$, natomiast przepisy polskie stanowiły, że obwiniony sędzia mógł wybrać obrońcę spośród sędziów, prokuratorów lub adwokatów ${ }^{67}$. Nowość dodaną po unifikacji stanowiło dopuszczenie obecności na rozprawie dwóch mężów zaufania, wskazanych przez obwinionego spośród sędziów lub prokuratorów ${ }^{68}$. Było to ciekawe rozwiązanie, pozwalające na minimalizację zagrożeń dla niezawisłego sędziego, który odpowiadał dyscyplinarnie $\mathrm{w}$ postępowaniu tajnym. Według rozporządzenia

${ }^{60}$ Art. 183 p.u.s.p.

${ }^{61}$ Art. 184 p.u.s.p.

62 APT, SOG (1387), sygn. 649, k. 76.

63 APT, SOG (1387), sygn. 700, k. 14v.

${ }^{64}$ Art. 157 p.u.s.p. Zarządzenie zawierało określenie niejawnego charakteru rozprawy, jej miejsce, datę i godzinę, podstawę prawną jej zarządzenia, dane osobowe obwinionego, skład personalny składu sędziowskiego, osobę protokolanta oraz informację o obowiązku wezwania obwinionego; por. APT, SOG, (1387), sygn. 605, k. 16, 29-29v.

65 Według jednej z uchwał obwiniony miał stawić się „pod rygorem, że w razie nie[z]jawienia się obrońca jego do zastępstwa dopuszczony nie będzie”; APT, SOG (1387), sygn. 582, k. 113.

${ }^{66} \S 32$ p.u.d.

${ }^{67}$ Art. 145 p.u.s.p. Po 1932 r. odebrano możliwość korzystania z adwokata jako obrońcy.

68 Art. $146 \S 2$ p.u.s.p. 
z 1928 r., jeżeli w toku rozprawy ujawniono nowe przewinienie, sąd mógł wydać co do niego wyrok tylko za zgodą prokuratora i obwinionego lub jego obrońcy. W razie braku takiej zgody należało wszcząć osobne postępowanie ${ }^{69}$.

Przebieg rozprawy nie był szczegółowo regulowany ani w przepisach pruskich, ani p.u.s.p., musiał więc kształtować się analogicznie do procedury karnej. Rozpoczynała ją prezentacja sprawy, tj. odczytanie uchwały zarządzającej jej wyznaczenie, a także akt $z$ przeprowadzonego śledztwa ${ }^{70}$. Potem fakultatywnie (jeśli sąd „uznał to za potrzebne") przeprowadzano postępowanie dowodowe ${ }^{71}$. Ani ustawy pruskie, ani p.u.s.p., nie zawierały osobnych regulacji dotyczących środków dowodowych i postępowania dowodowego. $Z$ ich szczątkowych regulacji wynika akceptacja reguł charakterystycznych dla procedury karnej, zwłaszcza w zakresie zeznań świadków, ewentualnie opinii biegłych ${ }^{72}$. W postępowaniach dyscyplinarnych nieprzydatne i nieadekwatne były natomiast środki dowodowe w postaci: oględzin, rewizji i zatrzymania rzeczy. W praktyce najczęściej korzystano z zeznań świadków, zwłaszcza w sprawach dotyczących obyczajowości sędziów lub ich zachowań w trakcie wykonywania czynności procesowych, szczególnie rozpraw ${ }^{73}$. We wszystkich zbadanych postępowaniach ważną rolę odgrywały dokumenty tworzone $\mathrm{w}$ toku pracy przez samego sędziego lub w odniesieniu do niego przez jego przełożonych ${ }^{74}$. Osobnym środkiem dowodowym były oczywiście wyjaśnienia samego obwinionego, które miały większe znaczenie w postępowaniu dyscyplinarnym niż karnym ${ }^{75}$.

69 Art. 160 p.u.s.p.

${ }^{70} \S 30$ p.u.d. oraz art. 159 § 1 p.u.s.p.

71 Art. 159 p.u.s.p.

${ }^{72}$ W kontekście śledztwa: § 27 p.u.d. oraz art. 149 p.u.s.p. oraz rozprawy $\S 31$ i 33 p.u.d.

${ }^{73}$ APT, SOG, sygn. 615, k. 16v; sygn. 649 k. 84v; sygn. 735, k. 4-59.

${ }^{74}$ Sąd dyscyplinarny wykorzystywał akta spraw, w których obwinieni dopuszczali się nieprawidłowości; por. APT, SOG (1387), sygn. 605, k. 41. Zob. APT, SOG, sygn. 649, k. 84v; sygn. 735, k. 216.

${ }^{75} \mathrm{Z}$ analizowanych akt nie wynika jednak, by były one uwzględniane $\mathrm{z}$ pominięciem innych dowodów. W orzeczeniach widoczna jest za to duża empatia 
Procedowanie kończyło się przemówieniami prokuratora i obrońcy, przy czym wysłuchanie prokuratora było niezbędne do wydania wyroku $^{76}$. Głos przyznawano również obwinionemu, który przemawiał ostatni ${ }^{77}$.

Sąd dyscyplinarny rozstrzygał sprawę w formie wyroku, który zapadał po naradzie większością głosów ${ }^{78}$. Niekiedy zdarzało się, że po zakończeniu rozprawy, na odrębnym posiedzeniu niejawnym, sąd wydawał postanowienie o kosztach, jeśli nie znalazło się ono w pierwotnym wyroku ${ }^{79}$. Ze wszystkich posiedzeń sądu dyscyplinarnego, $w$ tym $z$ rozpraw, sporządzano protokoły. Funkcję protokolanta pełniła osoba wyznaczona spośród sędziów lub aplikantów ${ }^{80}$.

\section{6. Środki zaskarżenia}

Realizacją zasady wieloinstancyjności postępowania dyscyplinarnego, podobnie jak w procedurze karnej, była możliwość zastosowania środków zaskarżenia w celu uchylenia bądź zmiany zapadłego już orzeczenia. Na gruncie przedwojennej procedury dyscyplinarnej

i zrozumienie dla specyfiki pracy sędziowskiej; por. APT, SOG (1387), sygn. 615, k. 16v; sygn. 649 , k. 84v. Trzeba przy tym przyznać, że w sprawach mniej poważnych i wynikających $z$ błędu sędziowie często uczciwie przyznawali się do winy; por. APT, SOG (1387), sygn. 605, k. 19v; sygn. 615, k. 127v. Niekiedy potwierdzali część ustaleń; por. APT, SOG (1387), sygn.57, k. 132-132v. Sporadycznie odmawiali wyjaśnień; APB, SOB (65), sygn. 691, k. 74v.

${ }^{76}$ Art. $143 \S 1$ p.u.s.p.

$77 \S 30$ p.u.d. oraz art. 159 § 2 p.u.s.p.

78 Art. 142, 161 i 163 § 2-3 p.u.s.p. Zachowane teksty wyroków sądów dyscyplinarnych: APT, SOG (1387), sygn. 582, k. 116-120v; APT, SOG (1387), sygn. 605, k. 40-41v; APT, SOG (1387), sygn. 735, k. 222-226.

${ }^{79}$ Np. APT, SOG (1387), sygn. 615, k. 134.

80 Por. art. 144 p.u.s.p. Wymogi formalne protokołu regulowano w art. 164 p.u.s.p.: wymienienie członków składu orzekającego i osób uczestniczących w rozprawie, „przedstawienie przebiegu rozprawy” z uwzględnieniem zeznań świadków i wyjaśnień biegłych („znawców”). Protokół podpisywali, zgodnie z regułami biurowości, przewodniczący składu i protokolant. Zachowane protokoły posiedzeń i rozpraw: APT, SOG (1387), sygn. 605, k. 18-18v, 34-35v; APT, SOG (1387), sygn. 735, k. 217-218v. 
środki zaskarżenia dzielono na zwyczajne (służące odwołaniu się od wyroków nieprawomocnych) i nadzwyczajne (wnoszone przeciwko orzeczeniom prawomocnym) ${ }^{81}$. Zwyczajnym środkiem zaskarżenia było odwołanie od wyroku sądu dyscyplinarnego. $Z$ tej możliwości mógł skorzystać obwiniony oraz prokurator. Odwołanie od wydanego wyroku wnosiło się za pośrednictwem sądu I instancji ${ }^{82}$ do sądu wyższej instancji ${ }^{3}$. Do postępowania odwoławczego miały zastosowanie przepisy o postępowaniu w I instancji ${ }^{84}$. W zakresie przebadanych spraw odwołanie wniesiono w trzech sprawach tylko w przypadkach skazania na wydalenie ze służby ${ }^{85}$. Wskazuje to na duży stopień akceptacji w odniesieniu do wydawanych orzeczeń dyscyplinarnych, gdyż sędziowie starali się je wzruszać tylko w sytuacjach ekstremalnych.

W zakresie nadzwyczajnych środków zaskarżenia widoczne jest zróżnicowanie między analizowanymi reżimami prawnymi. Według przepisów pruskich przeciw prawomocnemu wyrokowi przysługiwał tylko swoisty nadzwyczajny środek zaskarżenia nazywany „restytucją”. Takie rozwiązanie, w świetle możliwego stosowania procedury karnej $\mathrm{w}$ kwestiach nieuregulowanych ustawami $z$ lat 1851 i 1856, stało się kanwą pewnych kontrowersji. Jeden $z$ sędziów, skazany wyrokiem sądu dyscyplinarnego na karę usunięcia ze służby, po uprzednim wniesieniu odwołania, które nie zostało uwzględnione, zwrócił się $z$ wnioskiem o wznowienie postępowania, powołując się na obowiązujące przepisy procedury karnej. W uchwale Sądu Najwyższego z 26 kwietnia 1926 r. stwierdzono, że posiłkowe stosowanie procesowej ustawy karnej dotyczy wyłącznie kwestii nieuregulowanych w ogóle. Skoro w samej ustawie o odpowiedzialności dyscyplinarnej nadzwyczajne środki zaskarżenia

81 E. Krzymuski, op.cit., s. 185.

${ }^{82} \S 37$ p.u.d. oraz art. 165 p.u.s.p. Przepisy pruskie przewidywały termin czterech tygodni od dnia ogłoszenia wyroku lub jego dostarczenia oskarżonemu, polskie przewidywały termin siedmiu dni od daty doręczenia wyroku.

${ }^{83} \S 36$ p.u.d. oraz art. 165 p.u.s.p. Por. uwagi dotyczące właściwości sądów dyscyplinarnych.

${ }^{84} \S 41$ p.u.d. oraz art. $166 \S 2$ p.u.s.p.

85 Por. APT, SOG (1387), sygn. 649, 699 oraz APB, SAT (59), sygn. 50. 
doczekały się unormowania, wyłączało to możliwość stosowania w tym zakresie rozwiązań kodeksowych ${ }^{86}$.

Przepisy polskie znały nadzwyczajny środek zaskarżenia w postaci wznowienia postępowania ${ }^{87}$. Wniosek o wznowienie mógł być złożony przez skazanego (na jego korzyść) lub władzę nadzorczą (na jego niekorzyść), gdy wyszły na jaw nowe okoliczności lub dowody, mogące uzasadnić uniewinnienie, ewentualnie wymierzenie kary łagodniejszej ${ }^{88}$ albo skazanie lub wymierzenie kary surowszej. Jeżeli dopuszczono wznowienie postępowania na korzyść skazanego, to w nowym wyroku nie można było wymierzyć kary surowszej. Sąd rozpoznawał taki wniosek na posiedzeniu niejawnym, po uprzednim zażądaniu oświadczenia od strony przeciwnej i przeprowadzeniu w razie potrzeby śledztwa. Na uchwałę sądu w przedmiocie wznowienia postępowania służyła skarga do sądu wyższej instancji ${ }^{89}$. Jeżeli nowy wyrok był korzystniejszy dla obwinionego, to Skarb Państwa zwracał mu to, co utracił on na skutek poprzedniego wyroku, także koszty poprzedniego postępowania dyscyplinarnego ${ }^{90}$.

Co ciekawe, w toku badań archiwalnych znaleziono jeden przypadek, w którym skazany dyscyplinarnie sędzia złożył do Prezydenta RP wniosek $z$ prośbą o ułaskawienie, który jednak nie został uwzględniony ${ }^{91}$.

86 „Przepisy każdocześnie obowiązującej procedury karnej uzupełniają posiłkowo ustawę dyscyplinarną tylko wówczas, gdy w ustawie dyscyplinarnej są luki”. Regulowany w § 43 p.u.d. nadzwyczajny środek restytucji „wciela w skład sędziowskiej ustawy dyscyplinarnej te przepisy, które normują rzeczony środek odwoławczy [...]”, zatem „Przepisy te są wyczerpujące [...], nie wymagają uzupełnienia”; APB, SAT (59), sygn. 50, k. 38-40. W ustawie pruskiej wprost wyłączono możliwość składania kasacji - § 42 p.u.d.

${ }^{87}$ Art. $169-173$ p.u.s.p.

88 Art. 170 § 2 p.u.s.p. Było dopuszczalne także po śmierci skazanego z wnioskiem mogła wystąpić jego rodzina - żona i jego krewni w linii prostej, a także prokurator.

89 Art. 171 p.u.s.p.

90 Art. 173 p.u.s.p.

${ }^{91}$ APB, SAT (59), sygn. 50, k. 52. 


\section{Podsumowanie}

O wadze problematyki postępowań dyscyplinarnych wobec sędziów nie trzeba $z$ pewnością nikogo przekonywać. Model ich prowadzenia stanowi do dziś przedmiot zażartych sporów prawnych i politycznych. W tym kontekście refleksja historyczna wydaje się nieodzowna. Oferuje konieczną perspektywę i doświadczenia przeszłych pokoleń, zmagających się z podobnymi dylematami. Szczególnie ważny jest tu zaproponowany przez nas model badań aktowych, które analizują praktykę stosowania przepisów. Na przeszkodzie takim badaniom stoi niestety niekompletny stan zachowanych źródeł. Wiele problemów postępowań dyscyplinarnych przeciwko sędziom w dwudziestoleciu międzywojennym pozostanie dla nas na zawsze nieodkrytych.

Warto jednak podkreślić, że nawet taki niepełny materiał daje ciekawe rezultaty. Jak pokazaliśmy powyżej, międzywojenne sędziowskie postępowania dyscyplinarne miały nieco inne założenia niż współcześnie. Ich podstawowym celem była ochrona interesów i autorytetu wymiaru sprawiedliwości. Wynikała $z$ tego determinacja środowiska w tępieniu nagannych zachowań sędziów, zwłaszcza $\mathrm{w}$ sferze obyczajowej oraz $\mathrm{w}$ relacjach ze stronami i uczestnikami postępowań. Jednocześnie priorytetem było odcięcie opinii publicznej od wiedzy o tych epizodach, czemu służyła zasada tajności postępowania. W praktyce dawało to możliwość zakulisowego wymuszania rezygnacji na sędziach nienadających się do zawodu.

Na korzyść międzywojennych postępowań dyscyplinarnych przemawiają duża rzetelność i profesjonalizm w ich prowadzeniu. W przebadanych aktach raczej nie uwidacznia się ani nadmierna pobłażliwość, ani środowiskowa solidarność. Postępowania były jednak elastyczne w zakresie korzystania $z$ dostępnych instrumentów. Niektóre przeprowadzano szybko, w sposób odformalizowany, $z$ rezygnacją ze śledztw. Inne $z$ kolei to skomplikowane sprawy, wymagające skrupulatnego prowadzenia licznych czynności.

Przebadane akta wskazują na nie zawsze efektywny przepływ informacji w sądach, a także różną intensywność nadzoru przeło- 
żonych nad życiem prywatnym i wykonywaniem czynności zawodowych przez sędziów. Wiele zależało od indywidualnej postawy i zaangażowania kierownika sądu. W świetle skąpego materiału wygłaszanie $\mathrm{w}$ tym zakresie stanowczych twierdzeń byłoby jednak pochopne.

\section{STRESZCZENIE}

Proceduralne aspekty odpowiedzialności

dyscyplinarnej sędziów w II Rzeczypospolitej. Przebieg procesu

w świetle akt osobowych i dyscyplinarnych sądów

$\mathrm{z}$ terenów dawnego zaboru pruskiego

Odpowiedzialność dyscyplinarna sędziów stanowi fundamentalny problem współczesnych systemów prawnych państw konstytucyjnych. Z jednej strony musi być ona efektywna, by eliminować negatywne zachowania sędziów i budować zaufanie do wymiaru sprawiedliwości. $Z$ drugiej strony musiała szanować sędziowską niezawisłość, a także być odporna na próby jej użycia do ingerowania w rozstrzygnięcia sądów.

Autorzy prezentowanego artykułu podejmują próbę ukazania przebiegu procesów dyscyplinarnych przeciwko sędziom w II Rzeczpospolitej. Ich celem jest skonfrontowanie przepisów prawnych z praktyką ich stosowania, rekonstruowaną na podstawie zachowanych archiwalnych akt sędziowskich, zarówno osobowych, jak i dyscyplinarnych. Autorzy próbują także ukazać konsekwencje zasady tajności całej procedury, która teoretycznie mogła prowadzić do nadużyć i dawała władzom sądów możliwość radzenia sobie $z$ sędziowskimi przewinieniami nieoficjalnie (bez uciekania się do właściwej procedury dyscyplinarnej przeciw nim).

Słowa kluczowe: II Rzeczpospolita; odpowiedzialność dyscyplinarna sędziów; procedura dyscyplinarna; wymiar sprawiedliwości; sądy 


\section{SUMMARY}

Procedural aspects of disciplinary responsibility

of judges in the $2^{\text {nd }}$ Republic Of Poland.

The course of a process in the light of judges' personal

and disciplinary files from the old-Prussian territories.

Disciplinary responsibility is a crucial problem for every single modern legal system in constitutional states. On the one hand, it needs to be efficient, to eliminate judges' wrongful conduct and build trust towards the justice system. On the other hand, it has to be respectful to judges' independence and resilient to attempts of using it to influence court rulings.

Authors of the presented article try to show the course of procedure in disciplinary processes against judges in the $2^{\text {nd }}$ Republic of Poland. The goal is to confront legal provisions with their practical application, reconstructed based on remaining archival files of judges, both personal and disciplinary. Authors also try to show the consequences of secrecy of a whole procedure, which theoretically opened possibilities of abuses and allowed court authorities to deal with judges' misconducts unofficially (without using proper disciplinary procedures against them).

Keywords: $2^{\text {nd }}$ Republic of Poland; disciplinary responsibility of judges; disciplinary procedure; the justice system; courts; legal history

\section{BIBLIOGRAFIA}

Beynarowicz A., Ojak E., O odpowiedzialności dyscyplinarnej sędziów, „Czasopismo Sędziowskie” 1931, nr 5-6.

Czerwiński A., Ustrój sądów powszechnych, Lwów 1928.

Gołąb S., Organizacja sądów powszechnych opracowana systematycznie z uwzględnieniem rozwoju historycznego, sądownictwa szczególnego oraz ustroju adwokatury, prokuratorii generalnej i notariatu, Kraków 1938.

Gołąb S., Rosenblüth I., Ustrój sądów powszechnych, Warszawa 1929.

Historia państwa i prawa Polski 1918-1939, część II, red. F. Ryszka, Warszawa 1968.

Kędzierski T., Kilka uwag o sądach dyscyplinarnych dla sędziów i prokuratorów, „Głos Sądownictwa” 1934, nr 11. 
Koredczuk J., Wpływ nurtu socjologicznego na kształt polskiego prawa karnego procesowego $w$ okresie międzywojennym (Les classiques modernes), Wrocław 2007.

Kremens K., Jawność prokuratorskich postępowań dyscyplinarnych, „Prokuratura i Prawo” 2015, nr 5.

Krzymuski E., Wykład procesu karnego ze stanowiskiem nauki i prawa obowiąujaccego $w$ b. dzielnicy austrjackiej oraz z uwzględnieniem waźniejszych różnic na innych ziemiach Polski, Kraków 1922.

Krzyżanowski L., Sędziowie w II Rzeczpospolitej. Okręgi apelacyjne: krakowski i katowicki, Katowice 2011.

Kucharski T., Akta spraw sądowych i orzecznictwo sadowe $z$ okresu II RP jako źródło historyczne. Węzłowe problemy archiwalne i metodologiczne na przykładzie badań nad fideikomisami familijnymi, „Krakowskie Studia z Historii Państwa i Prawa” 2020, z. 1.

Ławnikowicz G., Idea niezawisłości $w$ porzadku prawnym i myśli prawniczej II Rzeczpospolitej, Toruń 2009.

Materniak-Pawłowska M., Ustrój sądownictwa powszechnego w II Rzeczpospolitej, Poznań 2003.

Materniak-Pawłowska M., Zawód sędziego $w$ Polsce $w$ latach 1918-1939, „Czasopismo Prawno-Historyczne” 2011, z. 1.

Mohyluk M., Prawo o ustroju sądów powszechnych w pracach Komisji Kodyfikacyjnej II Rzeczpospolitej, Białystok 2004.

Moniuk J., Udział prokuratora $w$ postępowaniach dyscyplinarnych przeciw sędziom i prokuratorom apelacji toruńskiej - okres międzywojenny, „Studia Iuridica Toruniensia” 2014, nr 14.

Paterski K., Zabezpieczanie dokumentacji osobowo płacowej zakładów pracy $w$ II pot. XX w. oraz u progu XXI w., „Problemy Archiwistyki” 2009, nr 1/1.

Waśkowski E., System procesu cywilnego, Wilno 1932. 